\title{
Radioadaptation of rodents in the zone of local radioactive contamination (Kyshtim Accident, Russia): 50 years on
}

\author{
E. Grigorkina and G. Olenev \\ Institute of Plant \& Animal Ecology, RAS Ural Branch, 8 Marta Str., 202, \\ 620144 Ekaterinburg, Russia
}

\begin{abstract}
Results of radioecological investigations of rodents having different ecological specialization wood and field mice, northern red-backed voles and mole-voles to acute (laboratory experiment) and chronic (long-term inhabiting the East Ural Radioactive Trace - EURT) irradiation are summarized. These species are greatly distinguished by a way of life, a migratory activity, an average life span etc. Numerous immunological, hematological and cytogenetical disturbances were found in more radioresistant wood and field mice and northern red-backed voles inhabiting the EURT zone (density of soil pollution by ${ }^{90} \mathrm{Sr}-18.5 \mathrm{MBq} / \mathrm{m}^{2}=500 \mathrm{Ci} / \mathrm{km}^{2}$ ) as compared with the reference samples. On the contrary there were no pathological shifts in more radiosensitive mole-voles from the more radioactively contaminated site $\left({ }^{90} \mathrm{Sr}-37 \mathrm{MBq} / \mathrm{m}^{2}=1000 \mathrm{Ci} / \mathrm{km}^{2}\right)$. The absorbed dozes during the life for the mole-voles from the EURT zone were significantly higher (in 30 times) than these ones for mice and voles. These data testify about the possibility of radioadaptation in a series of generations in mole-voles that developed due to their ecophysiological features and isolation of settlement in the radiocontaminated zone. Mice and voles form a flowing population and slip off the prolonged influence of a damaging factor, this circumstance prevents the development of radioadaptation.
\end{abstract}

\section{INTRODUCTION}

The Kyshtym radiation accident 1957 in the Southern Urals (Russia) resulted in the formation of the Eastern Urals Radioactive Trace (EURT) zone. This event is usually considered as one of the hugest catastrophes in the world nuclear industry practice. Large-scale radioecological researches (after Kyshtym and Chernobyl accidents) lead to revealing the phenomenon of radioadaptation [1-4]. However, the most part of these works was done on plants; the data on animals' radioadaptation are still quite scarce and fragmental. Up to now there is a distinct lack of quantitative data on the real longterm biological consequences of chronic radiation exposure lasting a long period of time [5]. Nowadays, the territory of EURT might be considered as a unique plot where comprehensive studies of long-term biological consequences of low-dose irradiation during the sequence of generations could be carried out, at least for small mammals inhabiting the zone of local radioactive contamination.

In the present work we aimed to show the results of investigations of radioresistance of small rodents both in acute trials (in laboratory experiment) and under chronic irradiation (dwellers of the EURT zone). Besides, we compared the species of different ecological specialization, trying to evaluate its importance for radioadaptation.

\section{MATERIAL AND METHODS}

\subsection{Sampling and analysis}

The objects of the study were several widespread rodents' species, substantially different in their ecological and physiological traits. Among these species common mole-voles (Ellobius talpinus Pallas, 1770) are subterranean borrowing animals with quite low migratory activity, which characterized by 
winter hibernation caused by both low ambient temperatures and lack of food. Mean life span of these rodents is up to 6 years. Wood mice (Apodemus (Sylvaemus) uralensis Pallas, 1811), field mice (Apodemus agrarius Pallas, 1771) and northern red-backed voles (Clethrionomys rutilus Pallas, 1779) are terrestrial rodents with high migratory activity, which is exhibited all the year round; their life span ranges from 3-4 months to 1.5 years in dependence of the type of ontogeny [6], which represented in figure 1. The studied specimens were captured at the plots with different densities by ${ }^{90} \mathrm{Sr}$ soil contamination: for mole-voles $-37 \mathrm{MBq} / \mathrm{m}^{2}=1000 \mathrm{Ci} / \mathrm{km}^{2}$, but for mice and northern red-backed voles $-18.5 \mathrm{MBq} / \mathrm{m}^{2}=500 \mathrm{Ci} / \mathrm{km}^{2}$.

Radioresistance and biological effects of chronic irradiation (e.g. haematological and immunological indices and frequencies of micronuclei occurrence in the bone marrow cells) were studied in animals inhabiting both the EURT zone and undisturbed territories of the Urals with global level of the ${ }^{90} \mathrm{Sr}$ pollution [7]. Radioresistance, which was considered as a characteristic determined by a species genotype [8], was assessed experimentally after acute irradiation $\left({ }^{137} \mathrm{Cs}\right)$ of animals by different doses, dose rate $-1.24 \mathrm{cGy} / \mathrm{sec}$.

\subsection{Two types of mouse-like rodents' ontogeny (fig. 1)}

This work was conducted on the base of functional approach [6]. This approach supposes to divide natural population of mice and voles into groups of individuals with the same functional status, i.e. with the uniform patterns of growth and/or maturation rate as well as whether they participate in reproduction.

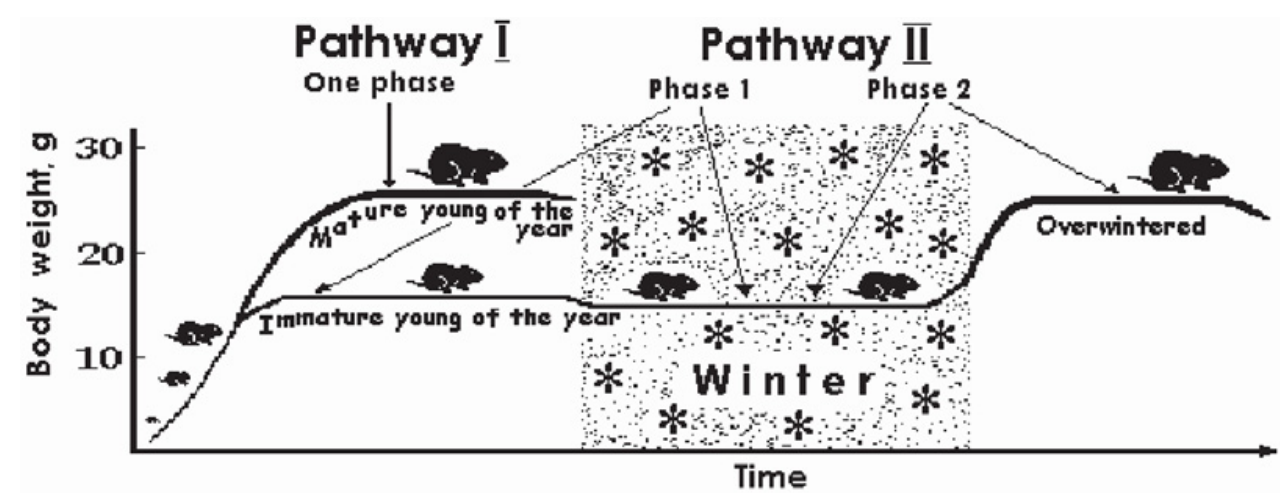

Figure 1. Scheme of two alternative pathways of mouse-like rodents' ontogenetic development [6].

Mature young of the year (the first type of ontogeny) are individuals that continue their growth and development (body mass $-25 \mathrm{~g}$ ), take part in reproduction, characterized by both high metabolic processes and rapid aging. Their function is increase in population numbers.

Immature young of the year (the second type of ontogeny, the first phase) are more resistant part of population. These individuals have body mass 16-18 g, growth is suspended, do not mature, characterized by both low metabolism and aging (two times). Their function is to preserve the corresponding part of the population (a state of "preserved youth") until the next spring with the smallest possible losses and, in the status of overwintered adults (the second type of ontogeny, the second phase), to begin the cycle of population renewal.

In our previous works we have shown [9] that individuals of different functional status manifest significantly diverse radioresistance by $\mathrm{LD}_{50 / 30}$, lethality after the same dose, average lifespan and reaction of the haemopoietic system. Such diversity is based on the differences in metabolic intensity of animals. Thus the functional approach should be use to the practice of radioecological studies, so 
its usage will substantially reduce errors and provide a better methodological basis for estimating the consequences of a wide range of deleterious factors in small rodents (mice and voles).

Among the other microtine rodents El. talpinus is peculiar in respect to not only its fossorial life but also specific deme organization of its populations, etc. [10].

\section{RESULTS AND DISCUSSION}

\subsection{Radioresistance of rodents}

For quite a representative series of tests of rodents ( 51 samples from which 25 are original data) we have established that mole-voles were the most radiosensitive specie [11]. Radioresistance of wood mice was 1.4 times higher, whereas field mice and northern red-backed voles were 2-2.5 times more radioresistant than mole-voles (table 1). High sensitivity of El. talpinus to the acute irradiation was at great extent linked with their ecological and physiological traits as well as with their habits. Development of preadaptation to the acute irradiation is apparently prevented in mole-voles by their relatively big body mass, inhabiting of borrows with quite constant micro-climatic conditions and the absence of natural insolation. Early we showed [12] that body mass, food habits, and biotopic inhabitance are significantly related to $\mathrm{LD}_{50 / 30}$ being those biological factors, which determines radioresistance of small rodents for ca. 40 per cent. It is essential to note that radioresistance in both mice, northern red-backed voles and mole-voles inhabiting the EURT zone were practically very close from that in reference populations.

Table 1. Radioresistance of rodents (acute irradiation) and absorbed doses per life and up to reproductive age (chronic irradiation in the EURT zone).

\begin{tabular}{|l|c|c|c|c|c|}
\hline Species & LD $_{50 / 30}, \mathrm{~Gy}$ & $\begin{array}{c}\text { Life } \\
\text { span, } \\
\text { years }\end{array}$ & $\begin{array}{c}\text { Absorbed dose } \\
\text { for life, } \\
\text { Rem [17] }\end{array}$ & Reproductive age & $\begin{array}{c}\text { Absorbed dose in } \\
\text { animals of } \\
\text { reproductive age, } \\
\text { Rem [17] }\end{array}$ \\
\hline $\begin{array}{l}\text { Wood mice } \\
\begin{array}{l}\text { Field mice } \\
\text { Northern red- } \\
\text { backed voles }\end{array}\end{array}$ & $\begin{array}{c}7.0 \pm 0.4 \\
10.0 \pm 0.2\end{array}$ & Up to 1.5 & $0.07-1.5$ & 1.5 months & 0.36 \\
\hline Mole-voles & $5.0 \pm 0.4$ & Up to 6 & $0.33-29.63$ & 2 years & 11.40 \\
\hline
\end{tabular}

\subsection{Biological effects and absorbed doses}

\subsubsection{Immunohaematological indices of mole-voles}

We revealed [13] that mole-voles from the EURT zone did not display any signs of damage of their most radiosensitive systems (haemapoiesis and immunity) while inhabiting the more radioactively contaminated plot than mice and voles did (table 2). They also did not show any morphological anomalies of blood cells as well as any differences by the frequency of chromosomal aberrations [14]. Some signs of activation of the immune system of animals were recorded: increase of the ratio of small lympholeucocytes, higher values of stimulation indices (percent of phagocyting neutrophyles, phagocytes number and specific activity of peroxidase of the blood) in comparison with a control group. Vaccination of animals showed the absence of differences between mole-voles from the impact and the background plots in titers of antibody to viruses of polyvalent dry vaccine "Trivac". Consequently, the reserved abilities and the functional activity of immune systems in mole-voles from the epicenter of EURT were higher than these in animals from the control site. One might conclude that long-term inhabitance of mole-voles in the epicenter of EURT (ca. 50 generations from the moment of accident) lead to compelled adaptation to the conditions of radiocontaminated biocoenosis. 
Table 2. Different indices of rodents from the EURT zone and undisturbed territories (a comparison).

\begin{tabular}{|l|c|c|c|}
\hline Species & $\begin{array}{c}\text { Frequency of } \\
\text { cells with } \\
\text { micronuclei }\end{array}$ & $\begin{array}{c}\text { Haematological } \\
\text { indices }\end{array}$ & $\begin{array}{c}\text { Immunological } \\
\text { indices }\end{array}$ \\
\hline Wood mice & $+^{*}$ & $+^{*}$ & $+^{*}$ \\
Field mice & $+^{*}$ & $+^{*}$ & $+^{*}$ \\
Northern red- & $+^{*}$ & $+^{*}$ & No data \\
backed voles & & - & - \\
\hline Mole-voles & - & & \\
\hline
\end{tabular}

Note: * significant differences, $\mathrm{p}<0.05$.

\subsubsection{Immunohaematological indices of mice and voles}

On the contrary, mice and northern red-backed voles from the EURT zone (more than 100 generations since 1957) displayed multiple alterations in the haemapoietic system, delays in the maturation of erythropoietic cells in the bone marrow, increase in the frequency of cells with micronuclei and the general lowering of the immune system functional activity (table 2) [13]. Besides, the ratio of small lympholeukocytes (the most active immunocompetent cells) in mice and voles was lowered, the number of structural anomalies of leukocytes increased, and some signs of violation of mitosis as well as some indications of haemopoietic process being more tensions were detected. Such structural violations of cells of the lymphopoietic group would inevitably change their functional activity and reserved possibilities. Lowering in the index of stimulation of phagocyte numbers as well as lowered relative activity of peroxidase might serve as an evidence of this. Significant increase in circulating of immune complexes was also revealed in mice. Besides, mice from the EURT zone displayed lesser antibody titer than animals from the control site.

\subsubsection{Phenogenetic analysis}

The results of phenogenetic analysis of wood mice from the EURT area indicated an increase in the ratio and variability of minor morphogenetic aberrations and deformations in the skull texture as well as an increase in the level of fluctuating asymmetry and deviation from the control in the frequency of phenes of nonmetric skull parameters [15].

\subsubsection{Concentration of ${ }^{90} \mathrm{Sr}$ and absorbed doses}

It is known that the most important role in the pathology of small mammals from the radiocontaminated territories originates from inherited effects. Individual parameters of ${ }^{90} \mathrm{Sr}$ concentration in the bone tissue of mole-voles varied up 225 to $1652 \mathrm{~Bq} / \mathrm{g}$; mean values of radionuclids' accumulation in northern red-backed voles and wood mice were $288 \pm 99 \mathrm{~Bq} / \mathrm{g}$ and $161 \pm 29 \mathrm{~Bq} / \mathrm{g}$, correspondently [16]. The total absorbed dose in the sequence of rodent generations (mice and northern red-backed voles) in EURT zone ranges from 6.0 to $27.0 \mathrm{~Gy}$ [17]. Such a wide range is evidence for unceasing gene exchange that takes place due to constant fluxes of migrants from relatively cleans to contaminated areas and vice versa. Therefore, the opinion concerning isolation of radiogenic groups of mice and voles in the Eastern Urals radiocontaminated Reserve is erroneous. Our results are supported by data [18] about significantly lower activity concentrations of ${ }^{137} \mathrm{Cs}$ and ${ }^{134} \mathrm{Cs}$ in yellow-necked mice (Apodemus flavicollus Melchior, 1834) than bank voles (Clethrionomys glareolus Shreber, 1780) in Belarus after the Chernobyl Accident.

It was also established that in the EURT zone absorbed doses, which have been accumulated in molevoles in the course both the pre-reproductive period of life and for the whole life span were significantly higher (up to 30 times) than in mice (table 1). This apparently is connected with the differences in ages of reproduction and in the mean life span as well as with more resident way of living of mole-voles. 
Besides, it might be caused also by that the isolated of mole-voles' population inhabited in the zone of higher level of ${ }^{90} \mathrm{Sr}$ contamination than mice and northern red-backed voles did.

\subsubsection{Configuration of the polluted area and ecological specialization of species}

Considering the possibilities of adaptation of small rodents to the technogenic environment, attention should first be paid to the configuration of polluted area and ecological specialization of species [19]. It is clear, that the necessary condition for the development of radioadaptation would be low migratory activity of the impact spatial group. It is known that mice are active all the year round doing seasonal interbiotopic migrations [20]; the mean length of their daily displacements is ca. $1.6 \mathrm{~km}$ under natural conditions. So, mice are able to pass through significant distances that are comparable with the crosssection size of contaminated zone. This lead to forming of a flowing population [19], i. e. a population with constantly changing set of individuals due to immigration from adjacent unpolluted territories and emigration from the contaminated zone. Such a feature is favored by the EURT zone configuration that looks like a prolonged and narrow territory having rapidly decreasing gradient of contamination. The maximum width of the trace with a ${ }^{90} \mathrm{Sr}$ soil contamination density of $1.0 \mathrm{Ci} / \mathrm{km}^{2}$ is about $10 \mathrm{~km} \mathrm{[21].}$ Since the transverse size of the cloud was small, radioactive fallout concentrated along the axis of its movement. So, the widths of area within different ${ }^{90} \mathrm{Sr}$ contamination densities in the study region are as follows: $1000 \mathrm{Ci} / \mathrm{km}^{2}-800 \mathrm{~m} ; 500 \mathrm{Ci} / \mathrm{km}^{2}-1400 \mathrm{~m} ; 250 \mathrm{Ci} / \mathrm{km}^{2}-1590 \mathrm{~m}$; and $50 \mathrm{Ci} / \mathrm{km}^{2}-1800 \mathrm{~m}$.

\section{CONCLUSION}

To sum up our new data one can conclude that mice and northern red-backed voles slip off the prolonged influence of a damaging factor, this circumstance preventing the development of radioadaptation. On the other side, the mole-voles are subterranean borrowing-dwellers with a low ability for dispersal. Besides, territorial insulation of their population in the EURT zone for a half-century history of the Kyshtym Accident promoted the development of radioadaptation in this specie. There are at least three possible explanations for this: (i) protective action of melanin [22], so all mole-voles were black, while in other parts of its area these animals exhibits polymorphism for the coat color; (ii) a specific unusual metabolic and genomic characteristics of El. talpinus, which could be associated with increased ability to repair breaks of DNA, inducible by radiation; (iii) a resistance to mutagenic influence of irradiation could evolve as a result of adaptation produced by heritable factors, which may have arisen under mutagenic pressure [14]. Their spreading in the population might be accelerated by genetic drift, due to marginal position this settlement in the EURT zone.

Hence, for the first time some convincing evidence of genetic radioadaptation of animals inhabiting the radiocontaminated zone during a long period and in the course of changing generations was obtained at the example of mole-voles (radiosensitive specie). The leading role in the development of radioadaptation is played by ecophysiological traits as well as by the main habits of a species. Besides, the configuration of contaminated zone is maybe not less important ecological factor.

\section{Acknowledgments}

This work was partly supported by RFBR (project 07-04-96091).

\section{References}

[1] Cherezhanova L.V. and Alexakhin R.M., Zhurn. Obsch. Biol., XXXII, 4 (1971) 494-500.

[2] Shevchenko V.A. and Pomerantseva M.D., Genetic Consequences of Ionizing Radiation Action. (Nauka, Moscow, 1985).

[3] Pozolotina V.N., Long - Term Radiation Effects on Plants. (Nauka, Ekaterinburg, 2003). 
[4] Geras'kin S.A., Evseeva T.I., Belykh E.S., Majstrenko T.A., Michalik B. and Taskaev A.I., J. Environ. Radioact., 94, 3 (2007) 151-182.

[5] Brechignac F., Policarpov G.G., Oughton D.H., Hunter G., Alexakhin R.M., Zhu Y.G., Hilton J. and Strand P., J. Environ. Radioact., 70 (2003) 155-159.

[6] Olenev G.V., Russian J. of Ecology, 33, 5 (2002) 321-330.

[7] Aarkrog A., Dahlgaard H., Nielsen S.P., Trapeznikov A.V., Molchanova I.V., Pozolotina V.N., Karavaeva E.N., Yushkov P.I. and Polikarpov G.G., The Sci. of the Total Environ., 201 (1997) 137-154.

[8] Lyubashevsky N.M. and Grigorkina E.B., Radiat. Prot. Dosim., 62, 1/2 (1995) 27-30.

[9] Olenev G.V. and Grigorkina E.B., Russian J. of Ecology, 29, 6 (1998) 403-407.

[10] Evdokimov N.G., Populational ecology of common mole-vole (Publisher Ekaterinburg, Ekaterinburg, 2001).

[11] Grigorkina E.B., Doklady Biological Sciences, 385, 2 (2002) 371-373.

[12] Grigorkina E.B., Radiats. Biol. Radioecol., 44, 3 (2004) 245-250.

[13] Grigorkina E.B. and Pashnina I.A., Radiats. Biol. Radioecol., 47, 3 (2007) 371-378.

[14] Gileva E.A., Radias. Biol. Radioecol., 42, 6 (2002) 670-673.

[15] Vasil'eva I.A., Vasil'ev A.G., Lubashevskii N.M., Chibiryak M.V., Zakharova E. Yu. and Tarasov O.V., Russian J. of Ecology, 34, 6 (2003) 405-412.

[16] Starichenko V.I., Radiats. Biol. Radioecol., 44, 3 (2004) 346-350.

[17] Lyubashevsky N., Bolshakov V., Gileva E., Grigorkina E., Golubev A., Romanov G., Starichenko V. and Chibiryak M., "Epicenter of the Urals Radiation Accident 1957: Dose Loads and Their Consequences in Small Mammals Generations Series", In: Radiation Research 1895-1995, Wurzburg 27 August - 1 September, 1995, Eds. Hagen U., Jung H., Streffer C. (10 ${ }^{\text {th }}$ ICRR Socity, Wurzburg, 995) 1, p. 426.

[18] Ryabokon N.I., Smolich I.I., Kudryashov V.P. and Goncharova R.I., Radiat Environ. Biophys., 44 (2005) 169-181.

[19] Grigorkina E.B. and Olenev G.V., "Role of Radiocontaminated Area Configuration in the Forming of Flowing Populations (as Exemplified by Rodents)", In: Radioactivity \& Radioactive Elements in Human Environment, Tomsk 18-22 October 2004, Ed. Richvanov L.P. (Tandem-Art Publishers, Tomsk, 2004) pp. 160-162.

[20] Kolcheva N.E., Sib. Ecol. Zhurn. 6 (2002) 811-818.

[21] Utkin V.I., Yurkov A.K., Nicolaev V.V. and Ribakov E.N., 2001. "About technogenic radiating situation in Urals", In: Biological effects of low dose ionizing radiation and radioactive pollution on environment BIORAD-2001, Syktyvkar 20-24 March 2001, Eds. Taskaev A.I., Kudyasheva A.G., Ermakova O.V. and Popova O.N. (Komi Scientific Center Ural Division of RAS, Syktyvkar, 2001) pp. 173-174.

[22] Mosse I., Kostrova L., Subbot S., Maksimenya I. and Molophei V., Radiat. Environ. Biophys., 39 (2000) pp. 47-52. 